\title{
Pengembangan Distribusi Luxpati Berbasis Ubuntu Sebagai Penunjang Proses Belajar Mengajar di Jurusan Pendidikan Teknik Informatika
}

\author{
Kadek Jeny Femila Devi ${ }^{1}$, I Ketut Resika Arthana ${ }^{2}$, I Gede Mahendra Darmawiguna ${ }^{3}$ \\ Jurusan Pendidikan Teknik Informatika \\ Universitas Pendidikan Ganesha \\ Singaraja, Bali \\ E-mail: kadekjenyfemiladevi@gmail.com¹, resika.arthana@gmail.com², igd.mahendra.d@gmail.com³
}

\begin{abstract}
Abstrak - Penelitian ini bertujuan untuk pengembangan Distribusi Luxpati Berbasis Ubuntu Sebagai Penunjang Proses Belajar Mengajar Mengajar di Jurusan Pendidikan Teknik Informatika. Ubuntu merupakan salah satu Distribusi Linux yang paling populer digunakan. Selain karena bersifat open source juga dikarenakan Ubuntu dilengkapi oleh beberapa aplikasi standar yang dibutuhkan oleh pengguna. Namun, baik ubuntu ataupun distro turunannya belum ada yang khusus dikembangkan untuk keperluan pemprograman, desain grafis dan jaringan.
\end{abstract}

Pengembangan Distribusi Luxpati Berbasis Ubuntu Sebagai Penunjang Proses Belajar Mengajar di Jurusan Pendidikan Teknik Informatika menggunakan siklus pengembangan perangkat lunak SDLC (Software Development Life Cycle) dengan model ADDIE, yaitu Analysis, Desain, Development, Implementation, dan Evaluation. Pada Distribusi Luxpati nantinya terdapat aplikasiaplikasi penunjang belajar-mengajar untuk Jurusan Pendidikan Teknik Informatika yang dibutuhkan oleh mahasiswa maupun dosen. Selain itu, proses remastering ini juga melingkupi pembuatan repository lokal, perubahan desain tampilan, pemberian identitas baru, penambahan command bahasa Indonesia pada terminal, serta pembuatan modul web penggunaan aplikasi.

Pengembangan Distribusi Luxpati ini diimplementasikan pada Ubuntu 12.04.4 LTS dengan software Remastersys. Seluruh kebutuhan fungsional telah berhasil diimplementasikan sesuai dengan rancangan dan telah diuji pengunaan pada hardware komputer yang berbeda dan kebenaran proses dari perangkat lunak Distribusi Luxpati.
Abstract - Linux distribution is a project which is developed with the objective to organize a set of Linux operating system software and to facilitate in the installation of Linux operating system. Ubuntu is one of the most popular Linux distribution which is used worldwide. With the open source characteristics, Ubuntu is equipped with some standard application which is useful for the user. However both Ubuntu and distro have no specific development for programming, graphic designing and networking purpose.

The development of Ubuntu based Luxpati distribution is used to facilitate the teaching and learning process at Jurusan Pendidikan Teknik Informatika by using SDLC (Software Development Life Cycle) and using ADDIE (Analysis, Design, Development, Implementation, and Evaluation). On the Linux Luxpati distribution, there were some application which support the teaching and learning program in Jurusan Pendidikan Teknik Informatika. This remastering process also included local repository development, new display design, giving new identity, giving additional command in Bahasa Indonesia, and also application for web development.

The development of Linux Luxpati was implemented into Ubuntu 12.04.4 LTS with software Remasterys. All functional requirements have been successfully applied based on the design and its implementation into different computer hardware has been tried out successfully.

Keyword - Linux, Remastering, Luxpati

\section{PENDAHULUAN}

Kata Kunci - Linux, Remastering, Luxpati 
Perkembangan teknologi di Indonesia dari tahun ketahun mengalami peningkatan yang signifikan. Pada segala aspek kehidupan, seperti pada bidang pendidikan, ekonomi, maupun pada pemerintahan, teknologi mulai dimanfaatkan secara maksimal. Kemajuan teknologi diiringi dengan pesatnya perkembangan perangkat lunak di Indonesia khususnya sistem operasi. Hal ini berdampak pada meningkatnya penggunaan software ilegal (bajakan) di kalangan masyarakat maupun pemerintahan. Berdasarkan riset Business Software Alliance (BSA) dan Ipsos Affair 2010 menyebutkan Indonesia berada di urutan ketujuh terhadap penggunaan software ilegal (tanpa lisensi). Aplikasi Microsoft merupakan software yang paling banyak dibajak oleh masyarakat Indonesia. Hal ini bukan tanpa alasan, sebab biaya yang dibutuhkan untuk pembelian satu paket lisensi sistem operasi mencapai jutaan rupiah. Permasalahan tersebut mengakibatkan masyarakat maupun instansi pemerintah harus mengeluarkan biaya yang tidak sedikit untuk mendapatkan Sistem Operasi Microsoft Windows maupun Sistem Operasi Machintosh. Di tengah permasalahan yang sedang dihadapi, pemerintah semakin giat mengarahkan Indonesia Go Open Source dari tahun 2009, hal ini sesuai dengan Surat Edaran Nomor:SE/01/M.PAN/3/2009 tentang Pemanfaatan Perangkat Lunak Legal dan Open Source Software (OSS) di lingkungan pemerintahan, lembaga pemerintah non departemen, dan lembaga lainnya.

Salah satu Open Source Software yang paling banyak digunakan oleh masyarakat dunia adalah Sistem Operasi Linux. Linux merupakan sebuah kernel sistem operasi yang dikembangkan dengan model hak cipta sumber terbuka atau open source [1]. Ketersediaan aplikasi open source pada sistem operasi Linux ini membuat banyak lembaga di pemerintahan maupun lembaga pendidikan memilih menggunakan sistem operasi yang bersifat terbuka, seperti Linux. Selain di lingkungan pemerintahan, universitas-universitas pun sudah mulai menerapkan penggunaan open source ini salah satunya Universitas Pendidikan Ganesha Singaraja.

Pendidikan Teknik Informatika merupakan jurusan di Universitas Pendidikan Ganesha dengan mata kuliah yang dipelajari antara lain Multimedia, Pemprograman, dan Jaringan selain terdapat mata kuliah umum dan mata kuliah kependidikan. Selama satu tahun terakhir PTI menerapkan PTI Go Open Source namun gaungnya kurang terdengar dan antusiasme mahasiswa masih terasa kurang. Banyak mahasiswa masih malas untuk menggunakan program dan sistem operasi yang bersifat open source, serta pengajar juga masih mengalami kesulitan untuk mencari aplikasi penunjang pembelajaran yang digunakan untuk mata kuliah yang diajarkan pada Sistem Operasi Linux. Selain itu, pengajar maupun mahasiswa juga mengalami kesulitan dalam menginstal program penunjang dikarenakan harus terkoneksi dengan jaringan internet dan keterbatasan informasi mengenai aplikasi open source di Linux. Keinginan Jurusan Pendidikan Teknik Informatika untuk mulai menggunakan aplikasi yang open source pun menurun hingga kembali menggunakan sistem operasi dan aplikasi yang tidak gratis, karena harus membayar dengan harga jutaan rupiah bahkan lebih, seperti sistem operasi Windows, Microsoft office, dan lain-lain.

Berlatar dari permasalahan kurangnya antusiasme mahasiswa menggunakan aplikasi dan sistem operasi yang bersifat open source, penulis mengajukan solusi terkait permasalahan itu, yaitu dengan Pengembangan Distribusi Linux "Luxpati" berbasiskan Distribusi Ubuntu sebagai Penunjang Proses Belajar-Mengajar pada Jurusan Pendidikan Teknik Informatika.

\section{KAJIAN TEORI}

\section{A. Sistem Operasi}

Sistem operasi (SO atau dalam bahasa Inggris operating system atau OS) adalah suatau software sistem yang bertugas untuk melakukan kontrol dan manajemen hardware serta operasioperasi dasar sistem, termasuk menjalankan software aplikasi, seperti program-program pengolah kata dan browser web. Secara umum sistem operasi adalah software pada lapisan pertama yang ditaruh pada memori komputer pada saat komputer dinyalakan. Sedangkan softwaresoftware lainnya dijalankan setelah sistem operasi berjalan, dan sistem operasi akan melakukan layanan inti umum untuk software-software itu.

\section{B. Linux}

Lahir dan berkembangnya linux diawali oleh Linus Benedict Torvald, mahasiswa Ilmu Komputer di Universitas Helsinki, Finlandia. Terinspirasi dari MINIX (Mini Unix), Linus mengembangkan sistem operasi komputer yang mirip UNIX dan melengkapinya dengan programprogram aplikasi. Inti dari sistem operasi (kernel) tersebut lalu dinamai seperti nama pembuatnya, Linux atau lebih tepatnya GNU/Linux. Sistem operasi Linux adalah salah satu alternative yang digunakan untuk menggantikan sistem operasi Windows. Perkembangan Linux sangat cepat 
karena sistem operasi ini dikembangkan oleh semua orang yang ingin mengembangkannya [2].

\section{Perkembangan Sistem Operasi GNU/LINUX}

Perbedaan mendasar antara Linux dan sistem operasi lainnya terletak pada Kernel Linux serta komponen-komponen dalam sistem yang bersifat bebas dan terbuka. Linux bukanlah satusatunya sistem operasi yang open source, walaupun demikian Linux adalah sistem operasi open source yang paling banyak digunakan. Beberapa lisensi perangkat lunak bebas dan sumber terbuka berdasarkan prinsip-prinsip copyleft, sebuah konsep yang menganut prinsip karya yang dihasilkan dari bagian copyleft haruslah merupakan copyleft [3]. GNU GPL adalah lisensi perangkat lunak bebas dalam bentuk copyleft, dan digunakan oleh kernel linux serta komponen-komponen dari proyek GNU.

D. Kelebihan dan Kekurangan Linux Kelebihan dan kekurangan Sistem Operasi Linux adalah sebagai berikut.

1. Kelebihan Linux

a. Bersifat free.

b. Lengkap dan powerful.

c. Didukung oleh banyak komunitas di seluruh dunia dalam hal dokumentasi dan penggunaan troubleshooting dan memperbaiki error.

d. Lebih tahan terhadap virus.

e. Kompatibel dengan berbagai processor komputer.

2. Kekurangan Linux

a. Kurang populer.

b. Ketergantungan paket aplikasi yang harus diunduh secara manual.

c. Deteksi perangkat keras yang kurang mendukung.

E. Repository Linux

Repository atau biasa disebut repo adalah tempat penyimpanan kumpulan aplikasi atau software yang digunakan untuk menginstal aplikasi tambahan di dalam sistem operasi yang berbasis Linux.

Repository di Ubuntu Linux dibagi ke dalam empat area yaitu sebagai berikut:

Main adalah software yang didukung secara resmi.

Restricted adalah software yang didukung tapi tidak seutuhnya free license

Universe adalah software yang dikelola oleh komunitas.

Multiverse adalah software yang tidak free.

\section{F. Arsitektur Linux}

Bagian terpenting sistem operasi adalah kernel, merupakan inti dari sistem operasi. Kernel mempunyai beberapa bagian penting adalah sebagai.

1. Manajemen proses

2. Manajemen memori

3. Driver-driver perangkat keras

4. Driver-driver sistem file

5. Manajemen jaringan

\section{G. Distribusi Linux}

Distribusi Linux merupakan sebuah proyek yang dikembangkan dengan tujuan untuk mengatur sekumpulan paket perangkat lunak yang berbasis sistem operasi Linux dan memfasilitasi dalam instalasi dari sebuah Sistem Operasi Linux. Distribusi Linux dikembangkan oleh individu, tim, organisasi sukarelawan dan entitas komersial. Distribusi Linux memiliki paket-paket perangkat lunak yang spesifik dirancang untuk instalasi dan konfigurasi sistem.

\section{H. Konsep Pembuatan Distribusi}

Ada beberapa metode pembuatan distro antara lain:

1. Pembuatan distro dengan berbasis Linux From Scratch (LSF) yaitu metode pengembangan distro secara mandiri dimana semua aplikasi dikompilasi dari kode sumber murni.

2. Membuat distro dari turunan distro besar yang sudah mapan, yang biasa dikenal dengan istilah remastering.

\section{Remastering}

Remastering adalah proses membuat master baru untuk sebuah album, film, atau ciptaan lainnya dari hasil cipta yang sebelumnya sudah ada[3]. Dalam bidang software, remastering dapat diartikan sebagai sebuah proses pembungkusan ulang paket aplikasi pada sistem operasi dimana kita bisa menambah dan mengurangi paket aplikasi yang disertakan. Penggunaan teknik ini diasosiasikan dengan distribusi Linux, yang mana sebagian besar dari distribusi Linux merupakan hasil dari proses remastering [4].

\section{J. Antarmuka Sistem Operasi}

Antarmuka pengguna Distribusi Luxpati dapat dilakukan dengan Command Line Interface (CLI) dan Graphical User Interface (GUI). Antarmuka sistem operasi pada Luxpati meliputi $\mathrm{X}$ Window System, Window Manager, dan Desktop Environment [1]. 
K. Aplikasi-Aplikasi Penunjang Pembelajaran

Aplikasi-aplikasi penunjang pembelajaran untuk Jurusan Pendidikan Teknik Informatika adalah aplikasi-aplikasi pada bidang pemprograman dianrtaranya : Free Pascal, Geany, Apache, PhpMyAdmin, MySQL, GCC, VirtualBox, PSPP, Monodevelop, Quanta, Bluefish, Netbeans, Lazarus, Google Earth, QGIS, QtOctave, dan Eclipse. Aplikasi penunjang di bidang desain grafis diantaranya : Blender, Inkscape, dan Gimp. Sedangkan aplikasi untuk jaringan adalah Wireshark dan Cisco Packet Tracer.

\section{Manajemen File}

Struktur direktori sistem operasi Linux berbeda dengan struktur direktori sistem operasi Windows. Ubuntu hanya mengenal satu direktori induk, yaitu root yang memiliki lambang “/” [1].

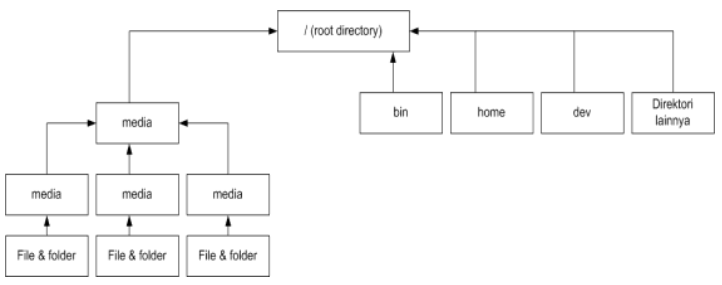

Gambar 1. Struktur direktori pada Linux/Ubuntu

\section{METODOLOGI}

Pengembangan Distribusi Linux Luxpati berbasis Ubuntu sebagai Penunjang Proses Belajar-Mengajar di Jurusan Pendidikan Teknik Informatika ini menggunakan model ADDIE (Analysis-Design-Develop-Implement-Evaluate). ADDIE sendiri merupakan singkatan dari tahapantahapan yang harus dilakukan untuk mengembangkan sistem yang terdiri atas Analisis, Perancangan, Pengembangan, Implementasi, dan. Evaluasi.

\section{A. Analisis Masalah dan Usulan Solusi}

Berdasarkan analisis yang penulis lakukan, Distribusi Linux merupakan sebuah sistem operasi open source dengan paket aplikasi yang telah disertakan dalam satu ISO Image. Sistem opersi ini lisensinya memberi kebebasan kepada pengguna menjalankan program apa saja, mempelajari dan memodifikasi program, dan mendistribusikan penggandaan program asli atau yang sudah dimodifikasi tanpa harus membayar royalti kepada pengembang sebelumnya [5]. Dalam distribusi Linux terdapat aplikasi standar yang dibutuhkan oleh pengguna, namun sebagian
Distribusi Linux memerlukan update aplikasi agar bisa digunakan. Sebagian besar aplikasi di sistem operasi Linux memerlukan koneksi ke jaringan intenet dalam proses installasi. Selain itu, interaksi antara pengguna dengan komputer pada sistem operasi Linux sebagian besar dilakukan melalui terminal atau console. Pengguna baru sistem operasi Linux tentu sangat asing dalam menggunakan terminal dan menuliskan command untuk melakukan perintah pada sistem operasi Linux dikarenakan command default yang disingkat serta menggunakan bahasa Inggris yang sulit dimengerti.

Berdasarkan permasalahan diatas penulis tertarik untuk mengembangkan Distribusi Linux Luxpati Berbasis Ubuntu Sebagai Penunjang Proses Belajar Mengajar di Jurusan Pendidikan Teknik Informatika. Usulan solusi Pengembangan Distribusi Linux Luxpati ini diterapkan untuk memudahkan pengguna, yaitu mahasiswa serta dosen Pendidikan Teknik Informatika dalam proses pembelajaran. Ketertarikan ini juga didasari pada kenyataan bahwa Indonesia merupakan negara dengan tingkat penggunaan software illegal yang tinggi khususnya software sistem operasi.

B. Analisis Perangkat Lunak

1. Kebutuhan Perangkat Lunak

Distribusi Luxpati ini dirancang agar dapat mengimplementasikan kebutuhan fungsional sebagai berikut.

a. Pada sistem yang dikembangkan terdapat aplikasi-aplikasi penunjang pembelajaran yang dibutuhkan oleh Jurusan Pendidikan Teknik Informatika.

b. Sistem dikembangkan dengan memodifikasi tampilan dari distribusi basis yaitu Distribusi Ubuntu.

c. Memiliki identitas baru yang berhubungan dengan Jurusan Pendidikan Teknik Informatika.

d. Menerima input berupa command bahasa Indonesia pada terminal selain command default yang digunakan pada bash shell.

e. Memiliki modul penggunaan aplikasi.

f. Terhubung dengan repository lokal yaitu repository baru selain repository yang sudah ditambahkan pada source list yang nantinya akan digunakan sebagai sumber aplikasi yang dibutuhkan oleh Luxpati.

Adapun kebutuhan non-fungsional dari aplikasi yang dikembangkan sebagai berikut. 
a. Tampilan Distribusi Linux Luxpati yang dibuat menarik dan user friendly sehingga mudah untuk dioperasikan pengguna.

b. Pengembangan repository lokal untuk memudahkan dalam instalasi aplikasi dan pembaharuan aplikasi yang dibutuhkan oleh pengguna.

\section{Tujuan Pengembangan Perangkat Lunak}

Aplikasi ini dikembangkan sebagai penunjang proses belajar mengajar di lingkungan Pendidikan Teknik Informatika. Aplikasi ini juga diharapkan dapat melakukan proses sebagai berikut.

a. Pada sistem yang dikembangkan terdapat aplikasi-aplikasi penunjang pembelajaran yang dibutuhkan oleh Jurusan Pendidikan Teknik Informatika.

b. Sistem dikembangkan dengan memodifikasi tampilan dari distribusi basis yaitu Distribusi Ubuntu.

c. Sistem yang dikembangkan memiliki identitas baru yang berhubungan dengan Jurusan Pendidikan Teknik Informatika.

d. Sistem dapat menerima input berupa command Bahasa Indonesia pada terminal selain command default yang digunakan pada bash shell.

e. Sistem yang dikembangkan memiliki modul penggunaan aplikasi.

f. Sistem yang dikembangkan terhubung dengan repository lokal, yaitu repository baru selain repository yang sudah ditambahkan pada source list yang nantinya akan digunakan sebagai sumber aplikasi yang dibutuhkan oleh Luxpati.

\section{Masukan dan Keluaran Perangkat Lunak}

Masukkan dari aplikasi yang dikembangkan adalah perintah dari user yang diinputkan melalui click mouse atau ketikan pada keyboard. Sedangkan keluaran dari Distribusi Luxpati yang dikembangkan adalah tampilan di monitor.

4. Model Fungsional Perangkat Lunak

Dalam pengembangan perangkat lunak ini, peneliti menggunakan flowchart untuk menjelaskan proses yang dilakukan dalam pengembangan perangkat. Flowchart merupakan penggambaran secara grafik dari langkah-langkah dan urut-urutan prosedur dari suatu program [6].

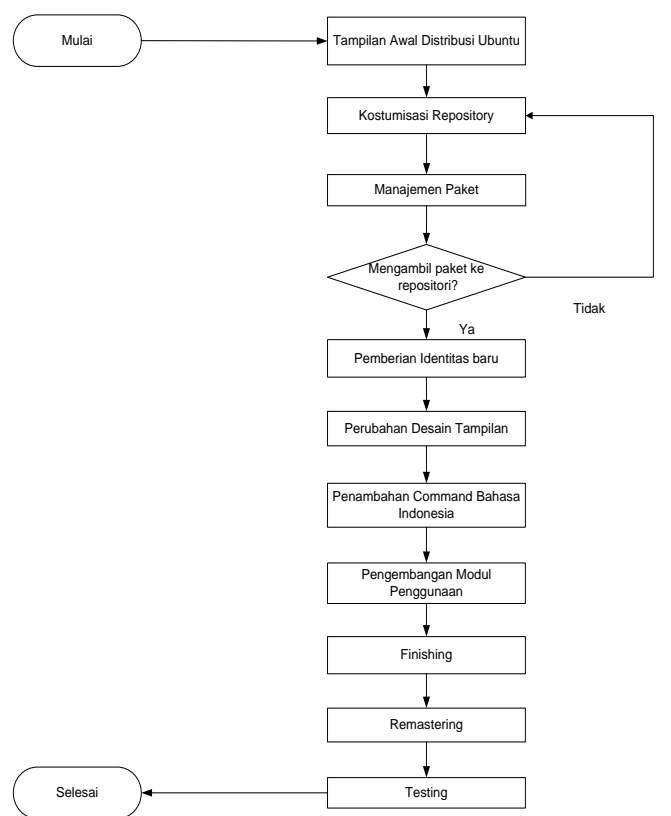

Gambar 2. Flowchart Pengembangan Distribusi Luxpati

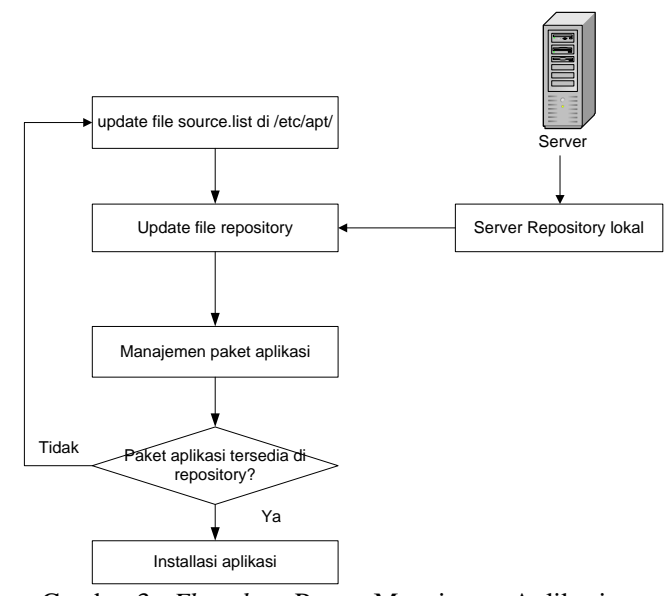

Gambar 3. Flowchart Proses Manajemen Aplikasi

C. Perancangan Perangkat Lunak

1. Batasan Perancangan Perangkat Lunak

Adapun batasan perancangan dari pengembangan distribusi ini, yaitu Distribusi Luxpati yang dikembangkan memuat aplikasi yang diperlukan dalam kegiatan pembelajaran di Jurusan Pendidikan Teknik Informatika selain aplikasi dasar yang diperlukan oleh pengguna, dimana pengguna nantinya bisa menambahkan sendiri aplikasi-aplikasi lain yang diperlukan selain aplikasi yang terinstal langsung.

2. Perancangan Arsitektur Perangkat Lunak Perancangan arsitektur Distribusi Luxpati sama seperti arsitektur sistem operasi pada umumnya. Arsitektur Distribusi Luxpati selain menggunakan Command Line Interface (CLI) juga 
dapat menggunakan Graphical User Interface (GUI).

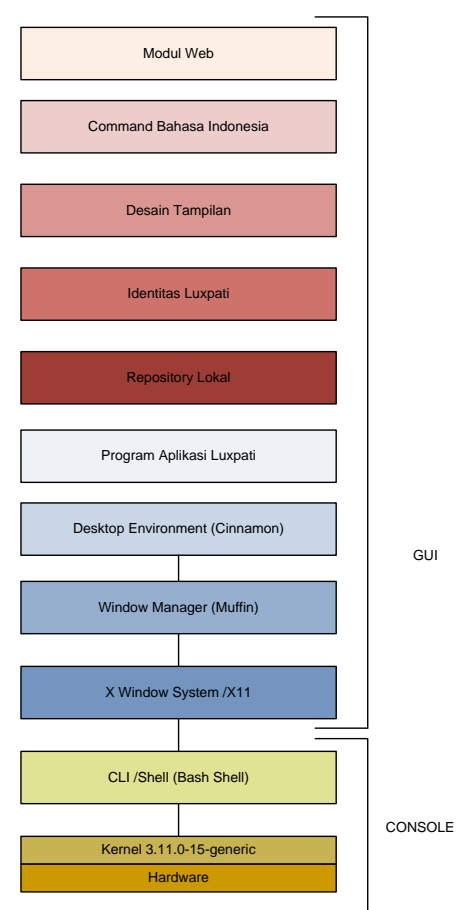

Gambar 4. Rancangan Arsitektur Distribusi Luxpati

3. Perancangan Antarmuka Perangkat Lunak Perancangan antarmuka perangkat lunak merupakan gambaran dari antarmuka aplikasi yang akan dikembangkan yang kemudian akan diimplementasikan pada tahap implementasi. Rancangan antarmuka perangkat lunak ini dituangkan dalam bentuk seperti berikut.

a. Rancangan Antarmuka Grub Loader

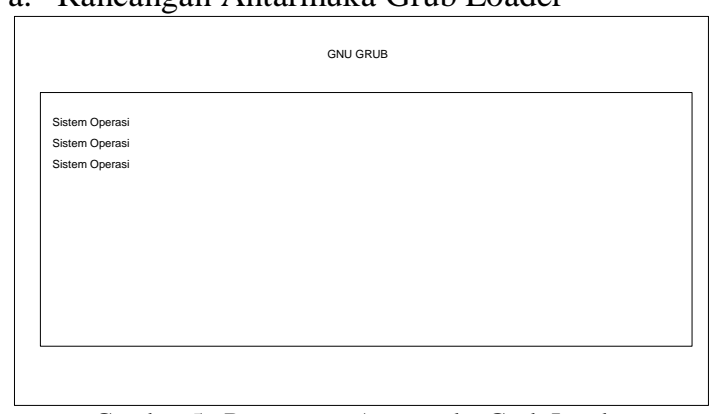

Gambar 5. Rancangan Antarmuka Grub Loader b. Rancangan Antarmuka Splash Screen

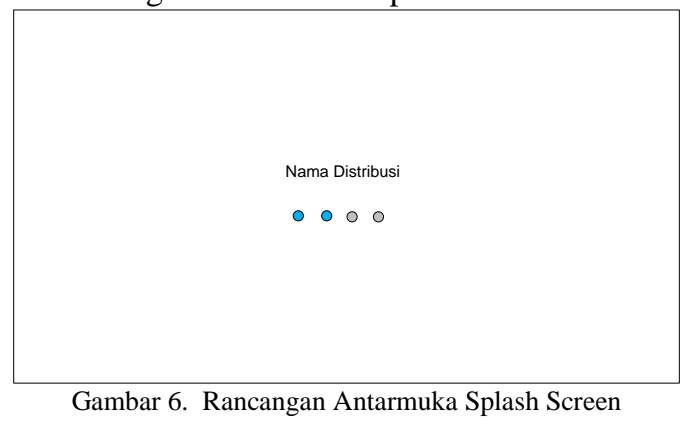

c. Rancangan Antarmuka Login Screen

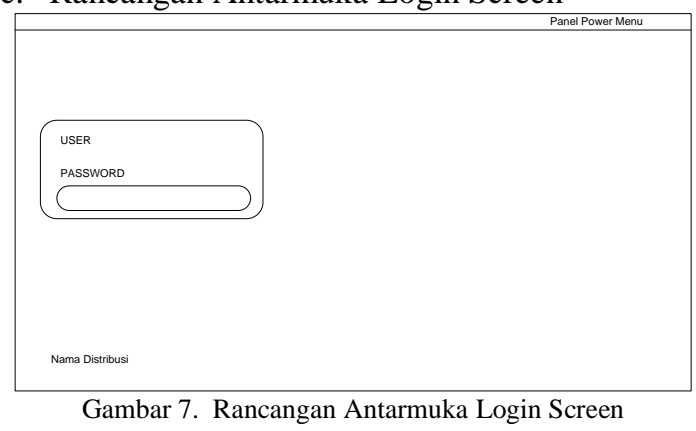

d. Rancangan Antarmuka Desktop

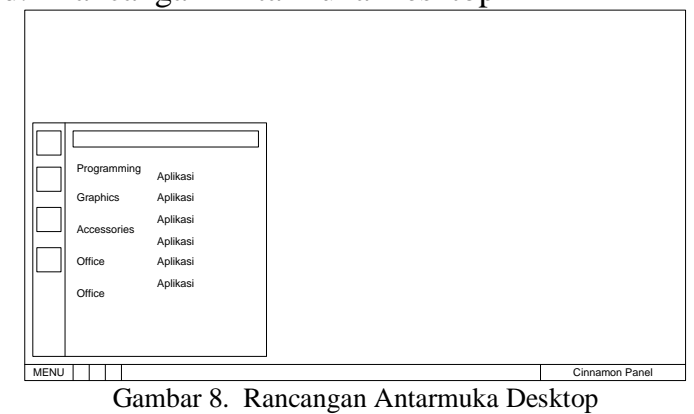


e. Rancangan Antarmuka Web Modul

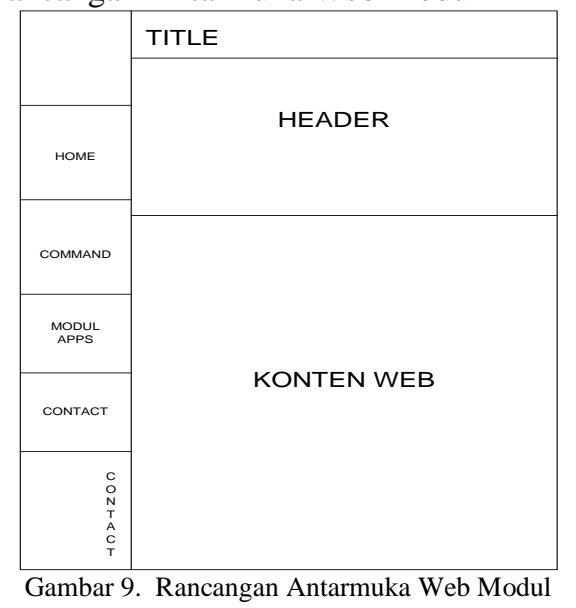

f. Perancangan Antarmuka Terminal

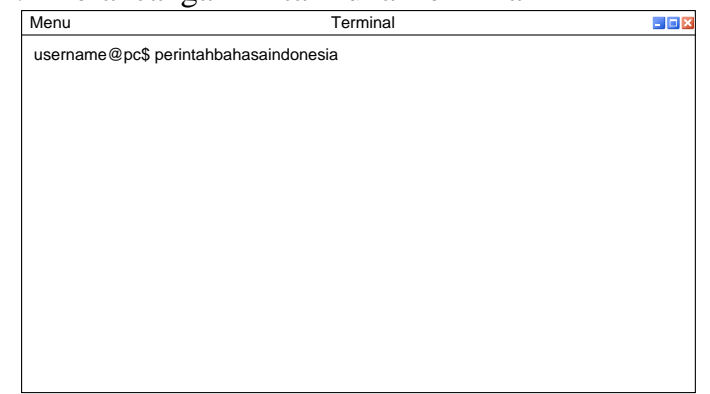

Gambar 10. Rancangan Antarmuka Terminal

\section{IV.PEMBAHASAN}

A. Implementasi Perangkat Lunak

1. Lingkungan Implementasi Perangkat Lunak Implementasi Pengembangan Distribusi Luxpati ini dilakukan pada lingkungan perangkat lunak dan perangkat keras sebagai berikut.

a. Ubuntu versi 12.04.4 LTS

b. Remastersys

c. VirtualBox

d. Adobe Photoshop CS 3

e. Bluefish

f. Apache Adapun lingkungan perangkat kerasnya, yaitu sebuah laptop dengan spesifikasi sebagai berikut.

a. Monitor 12,1 inchi dengan resolusi $1280 \mathrm{x}$ 800

b. Memori 3 GB RAM dan harddisk $320 \mathrm{~GB}$

c. Processor Intel® Dual Core $2.00 \mathrm{Ghz}$ Repository Luxpati akan dikembangkan pada laptop dengan spesifikasi sebagai berikut.

a. Monitor 10.1 inch dengan resolusi $1024 \times 600$

b. Memori 2GB RAM dan harddisk $320 \mathrm{~GB}$

c. RAM $1 \mathrm{~GB}$

d. Processor Intel Atom $1.8 \mathrm{GHz}$
2. Batasan Implementasi Perangkat Lunak

a. Processor Intel Atom $1.8 \mathrm{GHz}$

b. Kapasitas harddsik $17 \mathrm{~GB}$

3. Implementasi Antarmuka Perangkat Lunak Implementasi antarmuka dilakukan sesuai dengan rancangan antarmuka yang telah dibuat sebelumnya.

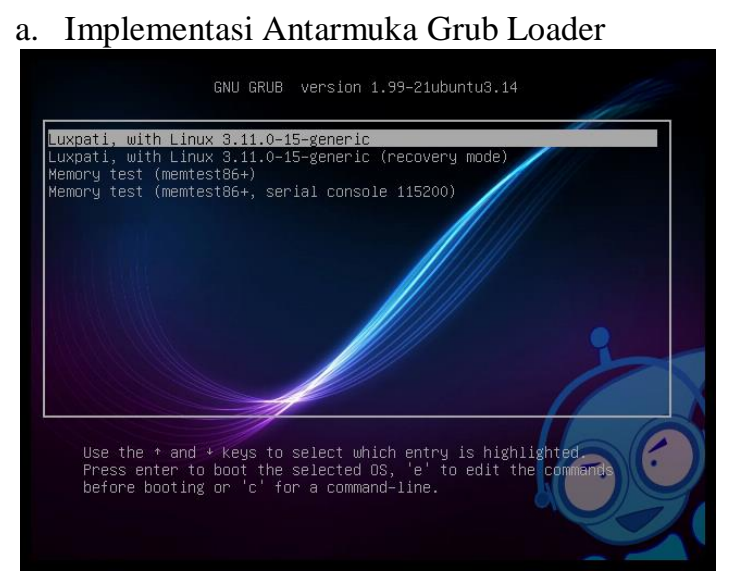

Gambar 11. Implementasi Antarmuka Grub Loader

\section{b. Implemenasi Antarmuka Splash Screen}

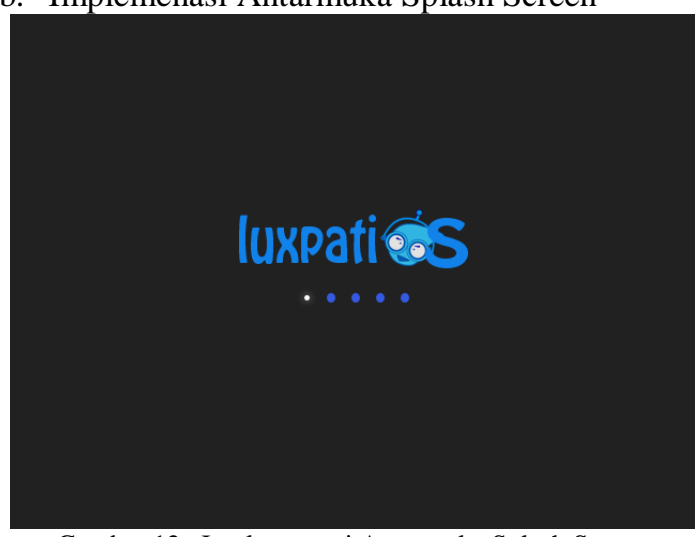

Gambar 12. Implementasi Antarmuka Splash Screen

c. Implemenasi Antarmuka Login Screen

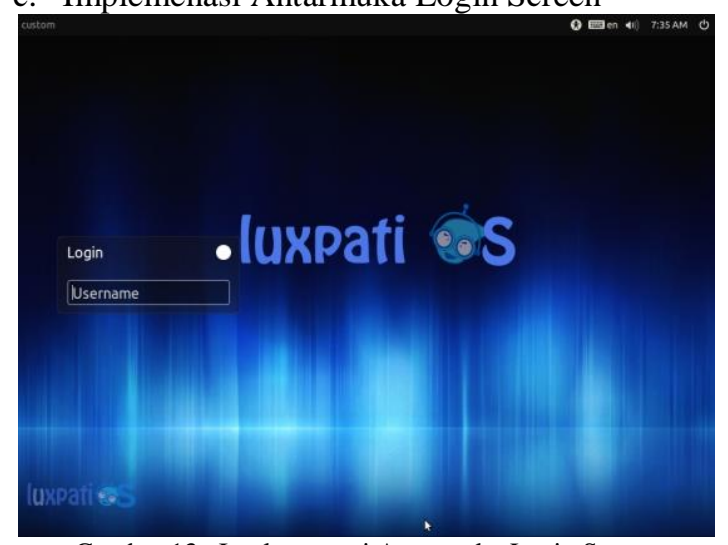

Gambar 13. Implementasi Antarmuka Login Screen 
d. Implemenasi Antarmuka Desktop

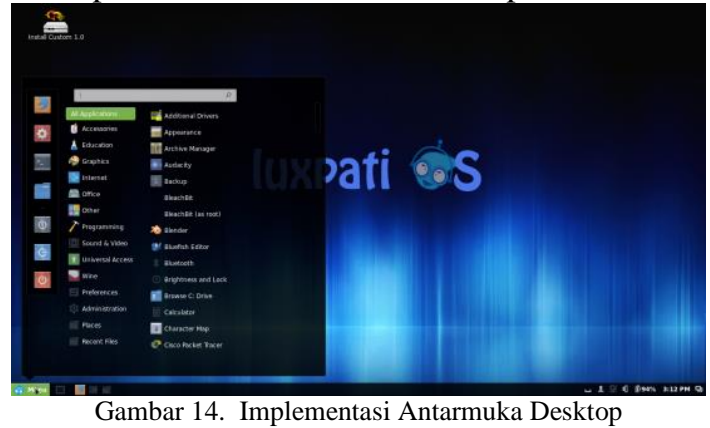

e. Implemenasi Antarmuka Details

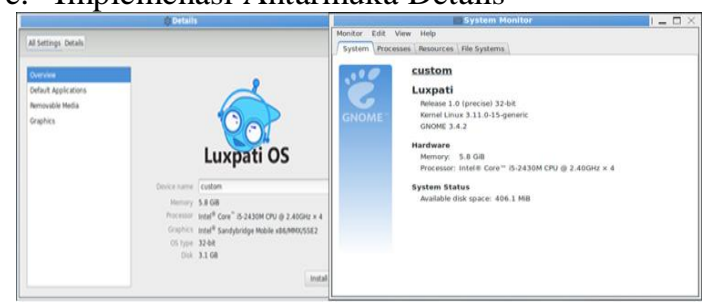

Gambar 15. Implementasi Antarmuka Details

\section{f. Implemenasi Antarmuka Web Modul}

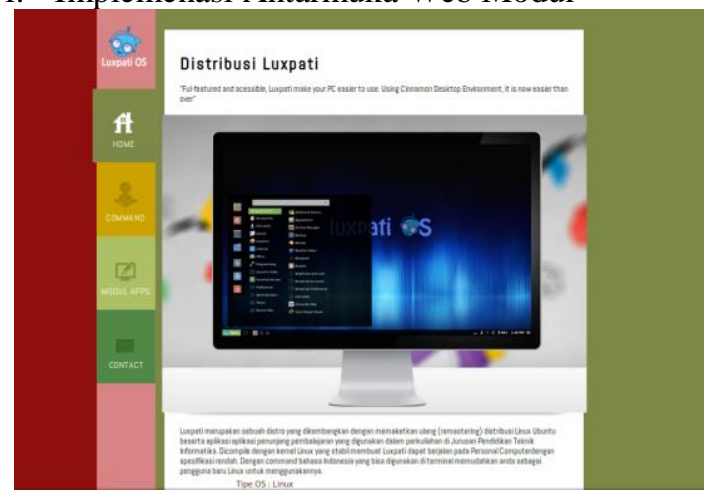

Gambar 16. Implementasi Antarmuka Web Modul

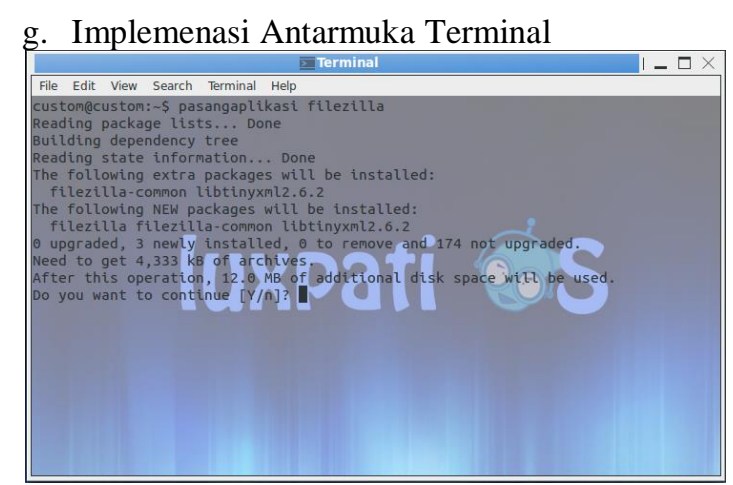

Gambar 17. Implementasi Antarmuka Terminal h. Implementasi Antarmuka Ubiquity Slideshow

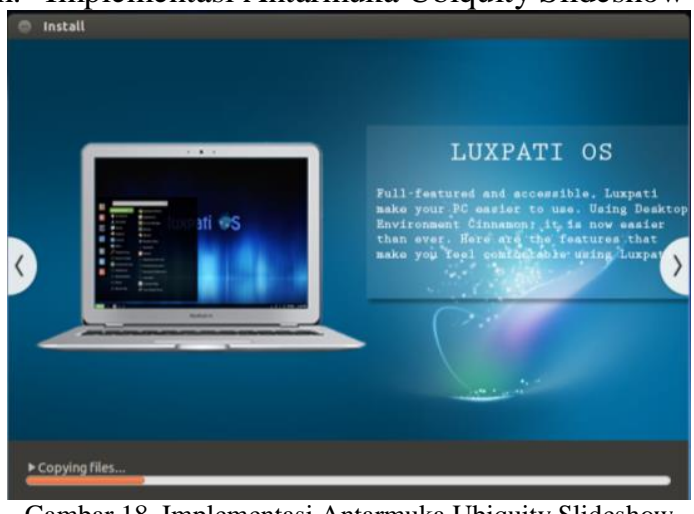

Gambar 18. Implementasi Antarmuka Ubiquity Slideshow

B. Pengujian Perangkat Lunak

1. Tujuan Pengujian Perangkat Lunak

Tujuan pengujian perangkat lunak Distribusi Luxpati yaitu:

a. Menguji penggunaan Distribusi Luxpati pada perangkat komputer yang berbeda.

b. Menguji kebenaran proses Distribusi Luxpati.

c. Menguji respon mahasiswa terhadap Distribusi Luxpati yang dikembangkan.

\section{Perancangan Kasus Uji Pengujian Perangkat} Lunak

Pada tahap ini bentuk dari uji kasus yang akan dilaksanakan dideskripsikan secara mendetail dan telah disesuaikan dengan tata ancang pengujian yang telah disusun sebelumnya. Terdapat dua uji kasus yang dirancang sesuai dengan tujuan pengujian perangkat lunak, yaitu menguji penggunaan Distribusi Luxpati pada perangkat komputer yang berbeda dan menguji kebenaran proses Distribusi Luxpati yang digambarkan pada angket pengujian.

\section{Pelaksanaan Pengujian Perangkat Lunak}

Pengujian perangkat lunak Distribusi Luxpati berbasis Ubuntu dilakukan oleh sepuluh orang yang berbeda yang terdiri atas tujuh mahasiswa Jurusan Pendidikan Teknik Informatika dan tiga orang dosen Jurusan Pendidikan Teknik Informatika dengan menggunakan beberapa perangkat komputer dengan merk dan spesifikasi yang berbeda. Pengujian dilaksanakan pada hari dan tempat yang berbeda.

\section{Evaluasi Hasil Pengujian Perangkat Lunak}

Berdasarkan pengujian penggunaan Distribusi Luxpati pada perangkat komputer yang berbeda diketahui bahwa perangkat lunak Distribusi Luxpati dapat dijalankan pada semua 
perangkat komputer yang diujikan sesuai dengan kebutuhan minimum aplikasi yang telah ditetapkan. Jika aplikasi dijalankan pada perangkat komputer yang tidak memenuhi kebutuhan minimum aplikasi, maka terdapat fitur yang tidak dapat berjalan dengan baik.

Berdasarkan pengujian kebenaran proses aplikasi Distribusi Luxpati diketahui seluruh proses dapat dijalankan. Sehingga seluruh fitur yang terdapat pada perangkat lunak Distribusi Luxpati dapat dijalankan dan tidak terjadi error. Jika terdapat crash system dikarenakan oleh penggunaan CPU Usage dan RAM yang tinggi pada perangkat komputer atau kernel yang masih tidak stabil dengan spesifikasi hardware yang digunakan.

\section{SIMPULAN}

Berdasarkan penelitian dan pengembangan Distribusi Luxpati berbasis Ubuntu Sebagai Penunjang Proses Belajar Mengajar di Jurusan Pendidikan Teknik Informatika yang telah dilakukan, maka diperoleh kesimpulan sebagai berikut.

1. LuxpatiOS merupakan sebuah Distribusi Linux yang dikembangkan sebagai penunjang proses belajar mengajar di Jurusan Pendidikan Teknik Informatika yang bersifat open source.

2. LuxpatiOS telah berhasil diimplementasikan sesuai dengan rancangan yang telah dibuat sebelumnya. LuxpatiOS diimplementasikan menggunakan bahasa pemprograman $\mathrm{C}$ dengan editor Geany serta Remastersys sebagai aplikasi pembuat master baru dari Distribusi Luxpati.

3. Fitur dari LuxpatiOS adalah repository lokal yang disediakan sebagai sumber aplikasi, command bahasa Indonesia yang dapat diinputkan di terminal dan web modul penggunaan aplikasi.

4. LuxpatiOS berbasis Ubuntu dapat berjalan pada perangkat komputer yang sesuai dengan spesifikasi minimal yang telah ditetapkan sebelumnya.

\section{REFERENSI}

[1]. Bowo, Eri.2010. Ubuntu From Zero. Jakarta:Jasakom.

[2]. Munawaroh, Siti. 2007. Penyaringan Akses Internet Menggunakan Squid di Linux. Jurnal Teknologi
Informasi DINAMIK Volume XII, No.1, Januari 2007 : 56-66

[3]. Agung, Wahyu.2010. Membuat DIstro Linux Sendiri. Balikpapan.

[4]. Santosa, Budi dkk.2010. Remastering Distro Ubuntu untuk Menunjang Pembelajaran. Jurnal Nasional Informatika 2010 (SemnasIF 2010).

[5]. Wheeler, David A.2014.Whay Open Source Software/Free Software (OSS/FS,FLOSS, or FOSS)? Look at the Numbers!. http://www.dwheeler.com/oss fs why.html (diakses tanggal 27 Juni 2014).

[6]. Adelia,dkk. 2011. Implementasi Customer Relationship Management (CRM) pada Sistem Reservasi Hotel berbasisi Website dan Desktop. Jurnal Sistem Informasi, Vol. 6, No.2, September 2011:113 - 126. 